ABDIMAS: Jurnal Pengabdian Masyarakat Universitas Merdeka Malang
Vol.6(4) November 2021, 629-639
p-ISSN: 2721-138X e-ISSN: 2548-7159
http://jurnal.unmer.ac.id/index.php/jpkm

\title{
Assistance in the preparation of Classroom Action Research articles and publications in reputable national journals
}

\section{Pendampingan penyusunan Artikel Penelitian Tindakan Kelas dan publikasi di jurnal nasional bereputasi}

\author{
Sri Asnawati, Irmawati Liliana Kusuma Dewi, Tri Nopriana, Siska Firmasari \\ Departemen Pendidikan Matematika, Fakultas Keguruan dan Ilmu Pendidikan, Universitas Swadaya Gunung Jati \\ J.. Perjuangan No. 01, Cirebon, 45132, Indonesia
}

\begin{abstract}
ARTICLE INFO
Received: 2021-03-24

Revised: 2021-05-03

Accepted: 2021-08-08
\end{abstract}

Keywords:

Classroom action research, Publication, Reputable journal, Scientific articles

\section{ABSTRACT}

Writing scientific papers is an important activity to improve teachers' quality, competence, and professionalism. Its implementation is marked by, among others, self-improvement through scientific research in the form of Classroom Action Research. During teaching and learning activities, teachers can research by developing various instruments and learning strategies. However, teachers rarely put their research results in writing in research reports and scientific articles. This community service activity aims to assist teachers in compiling Classroom Action Research reports and articles and explaining tricks to publish Classroom Action Research articles in reputable national journals. The implementation of the activities uses the methods of training, discussion, and direct mentoring so that the teacher can feel the process. This service activity received a good response, with the teacher's enthusiasm during the exercise, active discussions, and scientific reports and articles compilation. In the final discussion of this community service activity, teachers are very interested in publishing the results of their research, and it's just that teacher's lack information about reputable journals. Through this activity, the ability of teachers to research and publish their research results can become practical innovations in the world of education, especially classroom learning.

(C)2021 Published by University of Merdeka Malang. This is an open access article distributed under the CC BY-SA 4.0 license (https://creativecommons.org/licenses/by-sa/4.0/)

How to cite: Asnawati, S., Dewi, I. L. K., Nopriana, T., \& Firmasari, S. (2021). Assistance in the preparation of Classroom Action Research articles and publications in reputable national journals. Abdimas: Jurnal Pengabdian Masyarakat Universitas Merdeka Malang, 6(4), 629-639. https://doi.org/10.26905/abdimas.v6i4.5617

\section{PENDAHULUAN}

Penulisan karya ilmiah merupakan kegiatan penting dalam pengembangan profesionalisme guru (Noorjannah, 2014). Melalui kegiatan ini, guru akan terasah kemampuannya dalam menulis secara terstruktur, dan membaca referensi-referensi ilmiah yang berkaitan dengan pendidikan dan pengajaran. Berbagai hal dalam upaya perluasan pengetahuan dan keilmuan yang dimiliki merupakan bukti 
ABDIMAS: Jurnal Pengabdian Masyarakat Universitas Merdeka Malang Volume 6, No. 4, November 2021: 629-639

guru harus mengembangkan kompetensinya. Kompetensi yang wajib dimiliki guru ada empat, yaitu kompetensi pedagogik, kompetensi kepribadian, kompetensi sosial, dan kompetensi profesional (Sodiq et al., 2014). Keempat kompetensi tersebut telah diatur dalam Undang-undang RI Nomor 14 Tahun 2005 tentang Guru dan Dosen. Namun jarangnya melakukan penulisan karya ilmiah menyebabkan kurangnya motivasi dalam mengembangkan kompetensi guru (Qomariyah, 2015). Untuk itu perlu adanya pelatihan dan pendampingan secara berkala agar menumbuhkan semangat dan kesadaran akan pentingnya pengembangan diri, terutama yang berkaitan dengan menulis karya ilmiah. Berdasarkan hasil wawancara dengan beberapa orang guru SMA, kesulitan mereka dalam memulai menulis adalah ide atau inspirasi.

Inspirasi guru dalam menulis karya ilmiah sebenarnya dapat diperoleh dari hasil penelitian. Penelitian Tindakan Kelas (PTK) merupakan salah satu jenis penelitian yang paling memungkinkan dan sangat tepat, karena berkaitan langsung dengan perencanaan, proses, dan evaluasi dari kegiatan belajar-mengajar (Syahmani et al., 2020). Ada tujuh tahapan proses PTK, yaitu mengidentifikasi permasalahan, meninjau literatur, mengumpulkan data, menganalisis data, merencanakan strategi penelitian, pengambilan keputusan penyelesaian permasalahan di akhir pembelajaran, dan menginformasikan penyelesaian permasalahan (Habib, 2017). Selain itu, ada tiga unsur penting yang harus diperhatikan ketika akan menyusun PTK, di antaranya apa yang ditingkatkan oleh guru, pemilihan model pembelajaran yang mampu meningkatkan, dan subjek yang diupayakan untuk ditingkatkan (Oktoviana et al., 2020). Pada PTK, guru memberikan perlakuan khusus kepada siswa disetiap siklusnya berdasarkan informasi yang diperoleh dari siklus sebelumnya. Perlakuan yang diberikan oleh guru bertujuan untuk meningkatkan kualitas pembelajaran (Putri et al., 2019). Kualitas pembelajaran tercermin dari kemampuan guru dalam mengidentifikasi permasalahan di awal dan merencanakan tindakan yang tepat. Guru dapat menggunakan hasil PTK sebagai upaya untuk menemukan jawaban atau penyelesaian dari permasalahan yang mereka temui selama proses pembelajaran (Kunlasomboon et al., 2015).

Hasil dari Penelitian Tindakan Kelas dapat memberikan manfaat berupa refleksi dan pengembangan inovasi pembelajaran (Herlandy et al., 2018), untuk itu perlu adanya publikasi sehingga dapat terjangkau oleh kalangan luas (Dewi et al., 2019; Somatanaya et al., 2017). Publikasi dapat dilakukan melalui jurnal, seminar, paten, dan bentuk luaran lainnya. Berdasarkan Peraturan Menteri Negara Pendayagunaan Aparatur Negara dan Reformasi Birokrasi RI Nomor 16 Tahun 2009 Bab V Pasal 11, publikasi ilmiah merupakan salah satu kegiatan yang harus dilakukan guru dalam mengembangkan keprofesian secara berkelanjutan. Ada tiga bentuk publikasi ilmiah yaitu presentasi di forum ilmiah, publikasi hasil penelitian atau gagasan inovatif di bidang pendidikan formal, dan publikasi buku teks pelajaran (Rahyasih et al., 2020). Namun kenyataan di lapangan, banyak kendala yang ditemui oleh guru dalam melakukan publikasi ilmiah, di antaranya yaitu belum terbiasanya melakukan penulisan artikel ilmiah, minimnya informasi dan sumber referensi, serta porsi waktu yang lebih banyak difokuskan pada penyampaian materi pelajaran. Berdasarkan pengamatan yang dilakukan oleh Katamwatiningsih (2020) selama kurun waktu 4 tahun terakhir di beberapa kabupaten/kota di Provinsi Jawa Tengah menyimpulkan bahwa: (1) $75 \%$ guru yang mengikuti workshop, bimbingan teknis, atau pelatihan publikasi ilmiah belum pernah menuliskan pengalaman terbaik yang dialami; (2) 75\% guru belum pernah mengikuti fasilitasi pelatihan publikasi ilmiah; dan (3), 67,7\% guru dengan golongan III/b sampai IV/a yang terkendala kenaikan 
pangkat/golongannya karena mereka belum dapat memenuhi angka kredit dari sub-unsur publikasi ilmiah dan/atau karya inovatif.

Kendala yang terkait penulisan artikel ilmiah dan publikasinya yang terjadi di beberapa daerah juga dialami oleh guru-guru SMA di Majalengka. Kesimpulan awal ini diperoleh dari hasil diskusi dengan beberapa guru pada saat kegiatan survei lapangan bersama mahasiswa yang mengikuti program PPL. Menurut para guru mereka menemui kesulitan dalam menyusun laporan dan artikel ilmiah dari hasil penelitian serta mempublikasikannya. Keterbatasan informasi mengenai komponen-komponen yang harus terdapat dalam laporan dan artikel ilmiah yang sesuai dengan standar nasional, serta keterbatasan informasi berbagai bentuk publikasi ilmiah menjadi kendala terbesar para guru. Pada kenyataannya, guru-guru memiliki keinginan yang besar dalam melakukan penelitian dan mempublikasikannya, namun kendala tersebut masih sulit untuk diatasi. Seperti hasil pengabdian yang dilakukan oleh Muhali et al. (2019), bahwa sebenarnya guru dapat menulis laporan dan artikel ilmiah dengan baik, namun kendala terkait kesulitan akses informasi dan berbagai bahan referensi penelitian, serta membiasakan diri untuk menulis masih menjadi penghalang terbesar. Untuk itu, perlu adanya pelatihan dan pendampingan yang mampu untuk mengatasi kesulitan yang dialami. Guru-guru sangat antusias saat menerima tawaran untuk dilakukan pendampingan terkait penulisan laporan dan artikel ilmiah hasil penelitian tindakan kelas dan trik untuk mempublikasikan hasil penelitian tersebut di jurnal nasional bereputasi.

Berdasarkan uraian permasalahan yang telah dikemukakan sebelumnya, maka kegiatan pengabdian kepada masyarakat ini bertujuan untuk mendampingi guru dalam menyusun laporan dan artikel Penelitian Tindakan Kelas, serta menjelaskan trik mempublikasikan artikel Penelitian Tindakan Kelas di jurnal bereputasi nasional. Melalui kegiatan ini diharapkan guru-guru dapat meningkatkan kemampuannnya dalam menulis karya ilmiah dan mempublikasikannya sehingga hasil penelitiannya dapat bermanfaat secara luas, tidak hanya bagi internal guru, siswa dan instansi tempatnya mengajar namun juga bagi dunia pendidikan. Kegiatan ini dapat menjadi sarana peningkatan kompetensi profesional guru dalam menunjang pembelajaran yang berkualitas dan peningkatan jabatan akademik guru.

\section{METODE}

Kegiatan pengabdian kepada masyarakat ini berlokasi di SMA Negeri 2 Majalengka yang dilaksanakan pada Rabu, 17 Maret 2021 yang dihadiri oleh 27 guru dari berbagai bidang studi. Kegiatan awal dilaksanakan pukul 09.00-15.00 WIB, sedangkan proses pendampingan berlanjut selama 2 minggu berikutnya. Rangkaian acara menerapkan protokol kesehatan secara ketat sebagai syarat yang harus dipatuhi dalam kondisi COVID-19. Pelaksanaan diatur dengan sistematis oleh tim yang terdiri dari 3 dosen pemateri, 1 dosen sebagai penanggung jawab kegiatan, dan 2 mahasiswa yang membantu dalam persiapan peralatan serta dokumentasi. Tim telah menyusun rangkaian kegiatan yang prosedural dan teratur. Alur kegiatan pengabdian ini melalui beberapa tahapan seperti pada Gambar 1. 
ABDIMAS: Jurnal Pengabdian Masyarakat Universitas Merdeka Malang Volume 6, No. 4, November 2021: 629-639

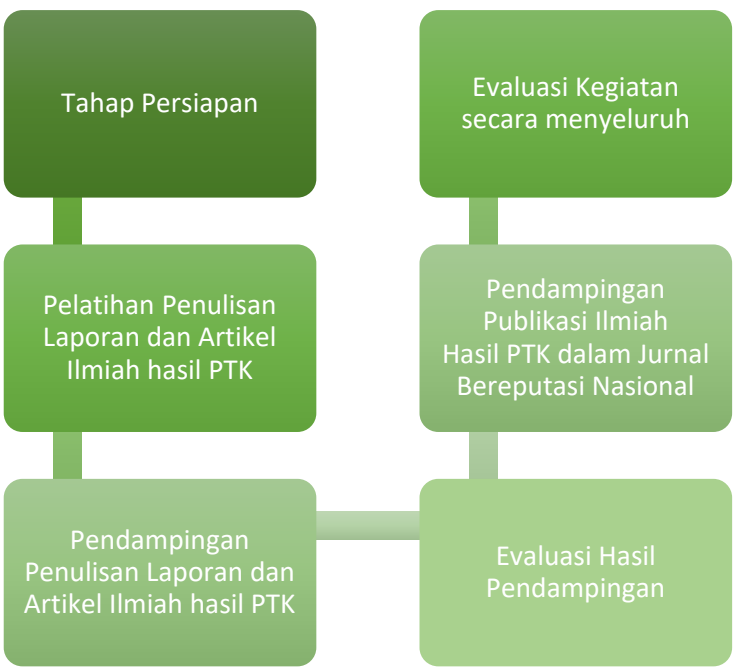

Gambar 1. Alur pendampingan penyusunan artikel ilmiah hasil PTK dan publikasinya di jurnal bereputasi nasional

Pada tahap persiapan, dilakukan sosialisasi program kepada guru-guru di SMA Negeri 2 Majalengka, mendata peserta, dan menyusun materi pendampingan. Kemudian pada tahap pelatihan, pemateri memberikan kerangka penulisan laporan dan artikel ilmiah sesuai standar nasional, serta memberikan contoh-contoh yang sesuai prosedur penulisan akademik. Berikutnya pada tahap pendampingan, guru mulai menulis hasil PTK dan menyusunnya sesuai dengan kerangka yang telah diberikan untuk laporan dan artikel ilmiah dengan bimbingan dari pemateri. Tahap evaluasi hasil pendampingan merupakan tahapan dimana tim melakukan refleksi dan meninjau kemajuan dari proses pendampingan yang telah dilakukan. Setelah diperoleh berbagai bentuk artikel ilmiah yang disusun oleh guru, kemudian pemateri mendampingi guru untuk mempublikasikan artikelnya ke jurnal bereputasi nasional, menyesuaikan dengan template jurnal tujuan, dan cara submit melalui OJS (Open Journal System). Akhir dari alur kegiatan ini berupa evaluasi secara keseluruhan, kendala yang ditemui selama proses kegiatan berlangsung, dan mengecek apakah semua permasalahan guru telah ditemukan solusinya secara tepat.

\section{Metode kegiatan}

Kegiatan pengabdian pada masyarakat ini melalui tiga metode yaitu ceramah, diskusi, dan simulasi. Ceramah dilakukan untuk memberikan penjelasan kepada guru-guru terkait PTK dan komponen penyusun laporan akhir serta artikel ilmiah berstandar nasional. Sedangkan diskusi dilakukan pada saat sesi akhir pelatihan dan selama proses pendampingan. Melalui metode ini memungkinkan peserta dapat menggali pengetahuannya mengenai cara penulisan sesuai prosedur akademik yang baik dan layak untuk dipublikasikan. Selain itu metode ini juga digunakan untuk tanya jawab terkait trik dan tips publikasi ilmiah di jurnal bereputasi nasional dari hasil penelitian. Metode terakhir yang diterapkan adalah simulasi, dimana guru-guru diberi informasi cara menyesuaikan template dari jurnal tujuan, dan submit ke jurnal bereputasi nasional melalui OJS. 


\section{HASIL DAN PEMBAHASAN}

\section{Hasil}

Kegiatan bertemakan "Pendampingan Penulisan Artikel Ilmiah Hasil Penelitian Tindakan kelas dan Publikasinya pada Jurnal Bereputasi Nasional" dikhususkan pada guru SMA Negeri 2 Majalengka. Kegiatan dilaksanakan di ruang guru dengan dihadiri oleh Kepala Sekolah, Wakil Kepala Sekolah bidang Kurikulum, dan guru-guru dari berbagai bidang studi. Survei awal berupa angket dibagikan kepada guru-guru selaku peserta pendampingan, dimana hasilnya tampak pada Tabel 1.

Tabel 1. Hasil angket respon awal terhadap kegiatan pengabdian

\begin{tabular}{lcc}
\hline \multicolumn{1}{c}{ Pertanyaan } & Respon & Persentase \\
\hline Apakah Bapak/Ibu pernah melakukan penelitian? & Ya & $60.9 \%$ \\
& Tidak & $39.1 \%$ \\
Jenis penelitian yang Bapak/Ibu lakukan? & PTK & $56.5 \%$ \\
& Lainnya & $21.8 \%$ \\
Apakah menurut Bapak/lbu PTK penting untuk dilakukan oleh guru? & Tidak Penah/Belum & $21.7 \%$ \\
Apakah Bapak/lbu sudah memahami betul metode penelitian PTK? & Ya & $100 \%$ \\
& Ragu-ragu & $56.5 \%$ \\
Apakah menurut Bapak/lbu PTK sulit untuk dilakukan? & Ya & $26.1 \%$ \\
& Ya & $73.4 \%$ \\
Apakah Bapak/lbu sudah pernah membuat artikel ilmiah dari hasil & Tidak & $26,1 \%$ \\
penelitian? & Tidak & $56.5 \%$ \\
Apakah Bapak/lbu pernah mempublikasikan artikel pada Jurnal & Ya & $43.5 \%$ \\
Imiah? & Tidak & $82.6 \%$ \\
Apakah menurut Bapak/lbu menulis artikel pada Jurnal Ilmiah & Ya & $17.4 \%$ \\
merupakan hal yang sulit? & Ya & $91.3 \%$ \\
\hline
\end{tabular}

Terlihat dari hasil pre-test pada Tabel 1, guru-guru SMA Negeri 2 Majalengka sudah melakukan penelitian termasuk penelitian tindakan kelas, namun mereka masih ragu apakah penelitian yang dilakukan sudah benar atau tidak. Kemudian para guru SMAN 2 Majalengka pernah menyusun artikel penelitian, namun mempublikasikannya adalah hal yang sulit. Berikut disajikan pengetahuan awal dari guru-guru beberapa bidang studi mengenai penulisan artikel hasil PTK dan publikasi ilmiah seperti yang tampak pada Gambar 2.

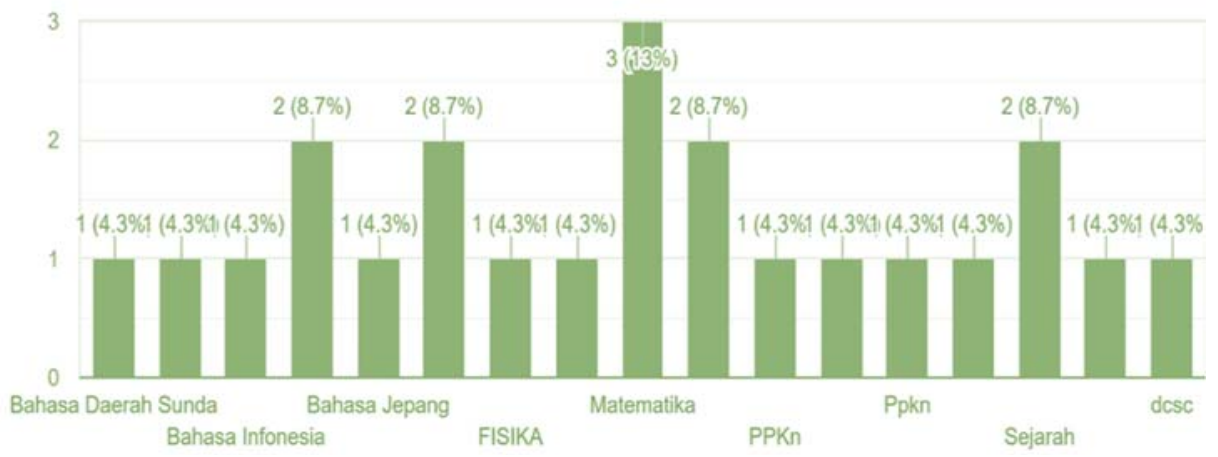

Gambar 2. Pengetahuan awal guru mata pelajaran mengenai penulisan PTK dan publikasi ilmiah 
ABDIMAS: Jurnal Pengabdian Masyarakat Universitas Merdeka Malang Volume 6, No. 4, November 2021: 629-639

Berdasarkan Gambar 2, pengetahuan awal guru matematika mengenai penulisan PTK dan publikasi ilmiah terlihat lebih menonjol, hal ini dikarenakan saat guru mengajar banyak menemukan permasalahan sehingga perlu diteliti lebih lanjut. Pada Gambar 3, terlihat guru perempuan lebih memahami mengenai penulisan PTK dan publikasi ilmiah.

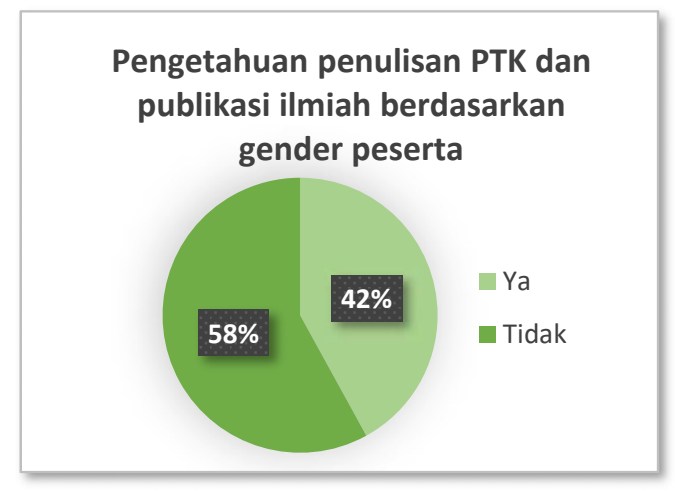

Gambar 3. Pengetahuan awal mengenai penulisan PTK dan publikasi ilmiah berdasarkan gender peserta

Setelah survei awal selesai dilaksanakan, tim PKM memberikan materi pertama mengenai Penelitian Tindakan Kelas (PTK) untuk angka kredit pengembangan keprofesian berkelanjutan bagi guru. Pada materi pertama banyak sekali pertanyaan-pertanyaan yang disampaikan oleh guru-guru mengenai syarat-syarat PTK yang baik agar lolos dalam mengajukan kenaikan pangkat. Pada penyampaian materi kedua dengan tema format laporan dan artikel ilmiah hasil PTK, guru begitu sangat memperhatikan dengan seksama penjelasan narasumber (Gambar 4).
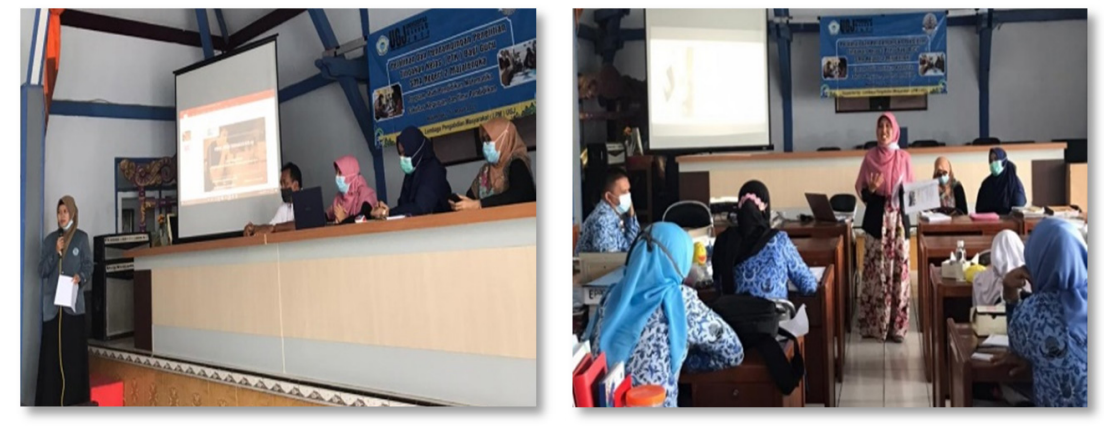

Gambar 4. Aktivitas penyampaian materi format laporan dan artikel ilmiah hasil PTK guru

Materi ketiga yang mengangkat tema mengenai publikasi artikel pada jurnal bereputasi nasional, peserta pelatihan juga tidak kalah antusias seperti materi sebelumnya. Para guru ternyata selama ini menganggap sulit untuk dapat mempublikasikan artikel pada jurnal. Setelah tiga materi selesai disampaikan oleh para pemateri, sesi selanjutnya dipergunakan untuk diskusi mengenai permasalahanpermasalahan yang ditemui para guru dalam menentukan ide, permasalahan dan tema PTK (Gambar 5). 

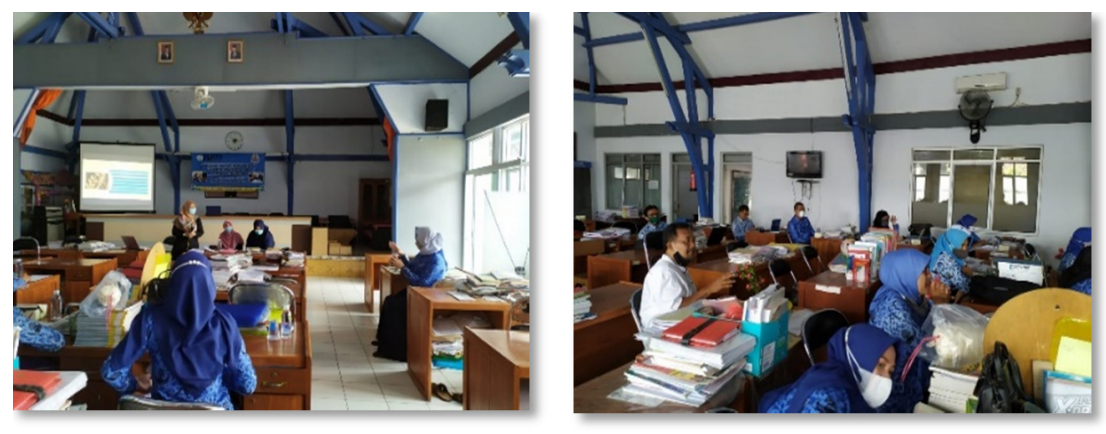

Gambar 5. Aktivitas penyampaian materi publikasi ilmiah dalam jurnal nasional bereputasi dan diskusi dengan peserta

Begitu antusias para guru SMA Negeri 2 Majalengka dalam berdiskusi dan mengutarakan permasalahan-permasalahan dalam bentuk pertanyaan kepada para pemateri. Setelah sesi diskusi selesai, kemudian tim PKM menginformasikan akan ada pendampingan melalui WhatsApp Group dan peserta pelatihan diberikan angket respon terhadap kegiatan pengabdian. Hasil angket respon peserta dapat dilihat pada Tabel 2.

Tabel 2. Respon guru setelah kegiatan pendampingan

\begin{tabular}{lcc}
\hline \multicolumn{1}{c}{ Pertanyaan } & Respon & Persentase \\
\hline $\begin{array}{l}\text { Apakah kegiatan pelatihan penulisan PTK dan Publikasi Ilmiah } \\
\text { memberikan manfaat bagi saya? }\end{array}$ & Ya & $100 \%$ \\
$\begin{array}{l}\text { Apakah kegiatan pelatihan penulisan PTK dan Publikasi Ilmiah } \\
\text { menarik? }\end{array}$ & Ya & $100 \%$ \\
$\begin{array}{l}\text { Bila ya, apakah kegiatan ini sesuai dengan kebutuhan Bapak/ } \\
\text { lbu? }\end{array}$ & Ya & $100 \%$ \\
$\begin{array}{l}\text { Setelah mengikuti pelatihan, apakah Bapak/lbu termotivasi un- } \\
\text { tuk melakukan PTK dengan lebih baik? }\end{array}$ & Ya & $85 \%$ \\
$\begin{array}{l}\text { Setelah mengikuti pelatihan apakah Bapak/lbu tertarik untuk } \\
\text { mempublikasikan artikel ilmiah pada Jurnal? }\end{array}$ & Ya & $15 \%$ \\
$\begin{array}{l}\text { Apakah Bapak/lbu memerlukan pelatihan yang lebih mendalam } \\
\text { mengenai PTK dan Publikasi Ilmiah? }\end{array}$ & Mungkin \\
$\begin{array}{l}\text { Bila ya, jenis pelatihan apa yang diperlukan? Mohon tuliskan } \\
\text { dengan lebih spesifik. }\end{array}$ & $\begin{array}{l}\text { Para Peserta membutuhkan pembimbingan dan Konsultasi } \\
\text { Penyusunan PTK dari awal menyusun proposal, penelitian, } \\
\text { melakukan siklus, penulisan laporan hingga publikasi dalam }\end{array}$ \\
\hline
\end{tabular}

Dari hasil angket respon pada tabel 2 diatas terlihat bahwa kegiatan pelatihan dan pendampingan penulisan Penelitian Tindakan Kelas (PTK) bagi guru SMA N 2 Majalengka direspon dengan sangat baik. Kegiatan pelatihan sangat menarik dan sesuai dengan harapan para peserta pelatihan. Para peserta pelatihan juga membutuhkan pembimbingan dan Konsultasi Penyusunan PTK dari awal menyusun proposal, penelitian, melakukan siklus, penulisan laporan hingga publikasi dalam jurnal. 
ABDIMAS: Jurnal Pengabdian Masyarakat Universitas Merdeka Malang

Volume 6, No. 4, November 2021: 629-639

\section{Pembahasan}

Kegiatan pengabdian mengenai penyusunan laporan dan artikel ilmiah hasil PTK ini memiliki kaitan dengan kebutuhan guru di masa kini dan masa yang akan datang dalam peningkatan kualitas diri serta kualitas pembelajaran. Kompetensi yang ditingkatkan guru tidak hanya terkait akademik saja, namun juga yang berkaitan dengan profesionalisme terutama di bidang penelitian dan publikasi ilmiah. Seperti yang menjadi visi Kementrian Pendidikan dan Kebudayaan tahun 2020-2024 ingin mewujudkan Indonesia yang berdaulat, mandiri, dan berkepribadian melalui terciptanya pelajar Pancasila yang bernalar kritis, kreatif, mandiri, beriman, bertakwa kepada Tuhan YME, dan berakhlak mulia, bergotong royong, dan berkebhinekaan global. Visi ini dapat terwujud dengan terciptanya pembelajaran yang inovatif dan sesuai dengan tujuan pembelajaran, menjadikan siswa bukan sekedar objek belajar namun tokoh utama pembelajaran yang mampu membuat dirinya mandiri dalam menemukan konsep-konsep pengembangan materi.

Salah satu unsur terpenting terwujudnya pembelajaran yang inovatif dapat dilakukan melalui penelitian berkala di kelas yang hasilnya dirasakan langsung oleh siswa dan guru. Perbaikan-perbaikan dari sisi strategi pembelajaran, pengembangan perangkat pembelajaran, dan instrument-instrumen yang terkait di dalamnya mampu meningkatkan kualitas pembelajaran yang berorientasi masa depan. Penelitian Tindakan Kelas menjadi sarana terciptanya guru kreatif dan selalu memiliki ide-ide baru dalam pembaharuan pembelajaran. Manfaat yang dirasakan pun dapat dibagikan melalui berbagai bentuk publikasi ilmiah.

Berdasarkan hasil wawancara di akhir kegiatan pengabdian terhadap perwakilan peserta ditambah pengamatan selama proses berlangsung, memberikan beberapa hasil sebagai berikut: (1) Pelaksanaan kegiatan pengabdian dirasakan manfaatnya secara langsung oleh peserta. Mereka menyatakan bahwa memang sudah lama sangat ingin adanya kegiatan seperti ini berlangsung, hanya kendala kondisi COVID-19 menjadi pengahalang terbesar acara tidak dapat dilaksanakan secara langsung. Karena menurut mereka, jika pelaksanaannya secara daring kurang dapat mengikuti dengan baik terkait koneksi internet yang terkadang di daerah yang memang tidak stabil; (2) Tersusunnya laporan dan artikel ilmiah, walaupun tidak semua peserta berhasil mengumpulkan pada batas waktu yang telah ditentukan, namun $60 \%$ telah menyelesaikannya dan tersusun sesuai dengan kerangka penulisan yang telah disampaikan pemateri. Kendala yang ditemui bagi yang belum sampai dengan produknya, dikarenakan kesulitan untuk menuangkan dalam bentuk tulisan terstruktur, sehingga waktu yang diperlukan bagi mereka masih dirasa kurang; (3) Artikel ilmiah yang telah berhasil disusun peserta kemudian sukses didampingi sampai dengan submit ke jurnal nasional bereputasi.

Terdapat beberapa faktor pendukung terlaksananya kegiatan pengabdian ini, di antaranya yaitu dukungan dari mitra berupa fasilitas tempat pelatihan dan keterlibatan peserta yang persentasenya tinggi, antusiasme dan minat peserta selama mengikuti kegiatan terlihat dari keaktifan pada saat berdiskusi dan tanya jawab serta produk yang dihasilkan sesuai dengan prosedur publikasi ilmiah, serta waktu yang disediakan oleh pihak mitra di sela kesibukan mereka menjadi bentuk tanggung jawab terhadap peningkatan kompetensi guru. Kondisi psikis guru yang penuh semangat, ditemui oleh beberapa pelaksana PKM lainnya, di antaranya Siregar (2011) serta Mulia \& Suwarno (2016), yang melihat respon 
positif dan keaktifan cukup tinggi dari guru-guru peserta pelatihan penyusun laporan PTK. Keterbukaan dalam menerima tim juga tampak dari komunikasi yang berjalan lancar dan perlakuan yang baik selama kegiatan berlangsung.

Faktor-faktor penghambat yang ditemui dalam PKM ini di antaranya adalah kesulitan beberapa peserta dalam menerapkan hasil penelitian ke dalam struktur artikel ilmiah, sehingga produk yang diinginkan belum sepenuhnya terealisasi sempurna. Hambatan kegiatan seperti ini ditemui pula oleh Dewi et al. (2019), dimana guru mengalami kesulitan penulisan pada bagian pendahuluan, metode, dan pembahasan. Secara umum hal ini dikarenakan belum terbiasanya guru menyajikan hasil penelitian dalam bentuk artikel ilmiah. Untuk itu guru-guru diharapkan kontinyu untuk menyusun karya tulis ilmiah berupa artikel hasil penelitian, agar pembelajaran di Indonesia selalu menemukan inovasi-inovasi baru dan berkembang sesuai dengan tuntutan zaman.

\section{SIMPULAN DAN SARAN}

Kegiatan pengabdian pada masyarakat ini memiliki tujuan untuk mendampingi guru dalam menyusun laporan dan artikel Penelitian Tindakan Kelas, serta menjelaskan trik mempublikasikan artikel Penelitian Tindakan Kelas di jurnal nasional bereputasi bagi guru-guru di SMA Negeri 2 Majalengka. Pelaksanaan meliputi tahap persiapan, pelatihan, pendampingan, dan evaluasi akhir. Kelancaran kegiatan menjadi perhatian khusus berkat dukungan dari mitra, kesiapan peralatan, dan kekompakan tim. Hasil yang dicapai berupa kemampuan guru menyusun laporan dan artikel ilmiah hasil Penelitian Tindakan Kelas (PTK) yang siap untuk dipublikasikan dalam jurnal nasional berepiutasi, serta membantu dalam usaha meningkatkan kompetensi profesional guru. Diharapkan melalui kegiatan ini, guru dapat lebih mengembangkan dirinya dalam bidang penulisan karya ilmiah dan terdorong untuk selalu mempublikasikan hasil tulisannya dalam berbagai bentuk publikasi ilmiah.

Guru perlu membiasakan diri dalammelakukan penelitian tindakan kelas agar kualitas pembelajaran meningkat, dan memberikan banyak manfaat bagi khalayak luas, khususnya untuk siswa dan guru sendiri. Selain itu harus memperbanyak referensi terkait informasi aktual dan terbaru dalam penyusunan karya ilmiah yang layak untuk dipublikasikan. Program pengabdian ini dapat ditindaklanjuti lebih luas wilayah cakupannya agar banyak guru yang dapat menulis artikel ilmiah layak terbit skala nasional maupun internasional. Pihak mitra dapat merekomendasikan kepada rekan sejawat mengenai kegiatan sejenis sehingga manfaatnya dapat dirasakan lebih banyak lagi.

\section{DAFTAR PUSTAKA}

Dewi, N. R., Yuliza, E., Eliyati, N., \& Faruk, A. (2019). Pendampingan merancang penelitian tindakan kelas dan penulisan publikasi kepada guru-guru SD di Desa Sakatiga. Jurnal Pemberdayaan: Publikasi Hasil Pengabdian kepada Masyarakat, 3(3), 367-372.

Habib, R. B. (2017). Students teaching students: An action research project incorporating active learning at language classroom. Journal of Education and Human Development, 6(2), 182-199. https://doi.org/10.15640/jehd.v6n2a20 
ABDIMAS: Jurnal Pengabdian Masyarakat Universitas Merdeka Malang Volume 6, No. 4, November 2021: 629-639

Herlandy, P. B., Ismanto, E., Novalia, M., \& Alrian, R. (2018). Pelatihan pelaksanaan penelitian tindakan kelas dan teknik publikasi jurnal ilmiah bagi Guru SMK Negeri 1 Rengat. Jurnal Pengabdian UntukMu NegeRI, 2(1), 38-42. https://doi.org/10.37859/jpumri.v2i1.418.

Katamwatiningsih, S. S. (2020). Pengembangan kurikulum diklat publikasi ilmiah sebagai bentuk fasilitasi peningkatan kompetensi guru dalam menulis best practice. Jurnal Edutrained : Jurnal Pendidikan Dan Pelatihan, 4(1), 35-44. https://doi.org/10.37730/edutrained.v4i1.58.

Kunlasomboon, N., Wongwanich, S., \& Suwanmonkha, S. (2015). Research and development of classroom action research process to enhance school learning. Procedia - Social and Behavioral Sciences, 171, 1315-1324. https://doi.org/10.1016/j.sbspro.2015.01.248.

Muhali, M., Asy'ari, M., Prayogi, S., Samsuri, T., Karmana, I. W., Sukarma, I. K., Mirawati, B., Firdaus, L., \& Hunaepi, H. (2019). Pelatihan kegiatan penelitian dan penulisan karya ilmiah bagi Guru Madrasah Aliyah Negeri 3 Lombok Tengah. Abdihaz: Jurnal Ilmiah Pengabdian pada Masyarakat, 1(1), 28. https://doi.org/10.32663/abdihaz.v1i1.739.

Mulia, D. S., \& Suwarno, S. (2016). PTK (Penelitian Tindakan Kelas) dengan pembelajaran berbasis kearifan lokal dan penulisan artikel ilmiah di SD Negeri Kalisube, Banyumas. Khazanah Pendidikan IX(2), 11.

Noorjannah, L. (2014). Pengembangan profesionalisme guru melalui penulisan karya tulis ilmiah bagi guru profesional di SMA Negeri 1 Kauman Kabupaten Tulungagung. Jurnal Humanity, 10(1), 11406.

Oktoviana, L. T., Hasanah, D., Sulandra, I. M., Susiswo, S., Lestari, T. E., \& Nurhakiki, R. (2020). Pendampingan penulisan artikel ilmiah dari hasil penelitian bagi guru matematika SMK Kota Kediri. Abdimas: Jurnal Pengabdian Masyarakat Universitas Merdeka Malang, 5(2), 115-122. https://doi.org/10.26905/abdimas.v5i2.3820.

Peraturan Menteri Negara Pendayagunaan Aparatur Negara dan Reformasi Birokrasi RI Nomor 16 Tahun 2009 Bab V Pasal 11.

Putri, S. S., Japar, M., \& Bagaskorowati, R. (2019). Increasing ecoliteracy and student creativity in waste utilization. International Journal of Evaluation and Research in Education, 8(2), 255-264. https://doi.org/10.11591/ijere.v8i2.18901.

Qomariyah, U. (2015). Pengembangan keprofesian berkelanjutan melalui penulisan artikel ilmiah bagi guru SD/ MI Kecamatan Sarang Kabupaten Rembang. Abdimas, 19(2), 135-142.

Rahyasih, Y., Hartini, N., \& Syarifah, L. S. (2020). Pengembangan keprofesian berkelanjutan: Sebuah analisis kebutuhan pelatihan karya tulis ilmiah bagi guru. Jurnal Penelitian Pendidikan, 20(1), 136-144. https://doi.org/10.17509/jpp.v20i1.24565.

Siregar, I. F. (2011). Pelatihan pengembangan laporan hasil penelitian tindakan kelas menjadi artikel ilmiah untuk jurnal bagi guru guru sekolah dasar Kota Semarang dalam upaya meningkatkan kompetensi profesional. Jurnal Abdimas, 15(2), 121-130.

Sodiq, I., Suryadi, A., \& Ahmad, T. A. (2014). Program guru menulis: Upaya peningkatan kompetensi profesional guru sejarah dalam penulisan karya ilmiah di Kabupaten Semarang. Rekayasa, 12(1), 42-47. https://doi.org/10.15294/rekayasa.v12i1.5586. 
Assistance in the preparation of Classroom Action Research articles and publications in reputable national journals Sri Asnawati, Irmawati Liliana Kusuma Dewi, Tri Nopriana, Siska Firmasari

Somatanaya, A. A. G., Herawati, L., \& Wahyuningsih, S. (2017). Pelatihan Penelitian Tindakan Kelas (PTK) bagi peningkatan karier guru-guru sekolah dasar Kota Tasikmalaya. Jurnal Pengabdian Siliwangi, 3(1), 169-175. http://jurnal.unsil.ac.id/index.php/jps/article/view/218/176.

Syahmani, S., Rusmansyah, R., Winarti, A., \& Almubarak, A. (2020). Penulisan artikel ilmiah berbasis Penelitian Tindakan Kelas (PTK) untuk meningkatkan kualitas pengajaran dan pembelajaran di SMA Banjarmasin Kalimantan Selatan. Jurnal Terapan Abdimas, 5(2), 163. https://doi.org/10.25273/jta.v5i2.5615.

Undang-Undang Republik Indonesia Nomor 14 Tahun 2005 Tentang Guru dan Dosen. 